\title{
Fasety na nowo odkryte. Integrowanie systemów nawigacji i organizowania informacji
}

\author{
Stanisław Skórka \\ Biblioteka Główna \\ Instytut Informacji Naukowej i Bibliotekoznawstwa \\ Uniwersytet Pedagogiczny w Krakowie
}

\begin{abstract}
Abstrakt
Cel/teza: Celem artykułu jest przedstawienie koncepcji i zasad działania nawigacji fasetowej (kierowanej) i wyszukiwania fasetowego oraz ich zastosowania w katalogach bibliotecznych.

Koncepcja/metody badań: Scharakteryzowano metodę organizowania dostępu do zasobów informacji za pomocą faset odpowiadających kryteriom wyszukiwania. Omówiono podstawowe cechy architektury informacji systemów wyszukiwania fasetowego oraz modele zachowań informacyjnych użytkowników, na podstawie których takie systemy są budowane. Analizie porównawczej poddano zastosowanie wyszukiwania fasetowego $w$ katalogach komputerowych na przykładzie katalogów elektronicznych (OPAC) pięciu bibliotek narodowych: Biblioteki Brytyjskiej (British Library), Biblioteki Kongresu (Library of Congress), Biblioteki Narodowej Walii (Llyfrgell Genedlaethol Cymru - National Library of Wales), Biblioteki Narodowej Australii (National Library of Australia) i Rosyjskiej Biblioteki Narodowej (Rossijskoj Nacionalnoj Biblioteki). Dane do analizy zbierane były od czerwca do września 2014 r. Wyniki i wnioski: Rozwój technologii informacyjnej doprowadził do odrodzenia koncepcji S. R. Ranganathana wieloaspektowego systemu klasyfikacji treści, ułatwiającego odszukanie informacji wieloma drogami. Klasyfikacja fasetowa jest dziś jedną z najczęściej stosowanych metod organizowania treści w serwisach internetowych o charakterze komercyjnym, choć większość autorów systemów kategoryzacji treści, które oparte są na tej klasyfikacji nie zdaje sobie z tego sprawy. Zastosowanie faset do zawężania rezultatów wyszukiwania jest już standardem w komercyjnych serwisach internetowych, w systemach bibliotecznych zaś innowacja ta nie jest jeszcze powszechna. Nie ma przyjętych czy zalecanych wzorców. W badanych katalogach zauważono różnice w liczbie kategorii oferowanych użytkownikom w interfejsach wyszukiwania fasetowego oraz ich nazewnictwie.

Oryginalność/wartość poznawcza: Tematyka wykorzystania faset i klasyfikacji fasetowej w mechanizmach wyszukiwania jest w Polsce rzadko poruszana. Autorowi nie są znane badania nad wykorzystaniem tego typu mechanizmu w serwisach internetowych związanych z działalnością informacyjno-biblioteczną.
\end{abstract}

\section{Słowa kluczowe}

Architektura informacji. Fasety. Katalogi biblioteczne. Klasyfikacja fasetowa. Nawigacja fasetowa. Systemy discovery and delivery. Wyszukiwanie fasetowe.

Otrzymany: 14.09.2014. Poprawiony: 03.11.2014. Zaakceptowany: 30.11.2014.

\section{Wstęp}

Jednym z osiągnięć bibliotekoznawstwa i nauki o informacji, które ma wyraźny wpływ na rozwój serwisów internetowych jest klasyfikacja fasetowa. Jej koncepcję w latach 30. XX w. opracował hinduski matematyk i bibliotekarz Shiyali Ramamrita Ranganathan i wykorzystał 
ją w budowie Klasyfikacji Dwukropkowej (ang. Colon Classification) - pierwszej klasyfikacji fasetowej przeznaczonej do organizowania informacji o piśmiennictwie. W tamtych czasach metoda Ranganathana okazała się zbyt pracochłonna i skomplikowana do praktycznego wykorzystania, dlatego niewiele ośrodków zastosowało ją do tworzenia charakterystyk wyszukiwawczych dokumentów (Bielicka \& Ścibor, 1982, 17). Do nielicznych wyjątków należy Biblioteka Uniwersytecka w Madrasie. Idea klasyfikacji fasetowej została jednak później rozwinięta i spopularyzowana jako metoda tworzenia specjalistycznych klasyfikacji biblioteczno-bibliograficznych, m.in. przez Classification Research Group (Zespół Badań Klasyfikacyjnych) w Wielkiej Brytanii (Bielicka \& Ścibor, 1982, 17; Sosińska-Kalata, 2002, 179). Obecnie klasyfikacja fasetowa jest jedną z najczęściej stosowanych metod organizacji treści w serwisach internetowych zawierających duże zasoby danych, takich jak: sklepy, bazy danych, porównywarki cen itp. Klasyfikacja fasetowa związana jest nie tylko z organizacją informacji, ale również integruje systemy wyszukiwania informacji wspierając zachowania informacyjne użytkownika poprzez m.in. prezentację filtrów ułatwiających wybór odpowiednich cech poszukiwanego obiektu.

Głównym celem niniejszego artykułu jest przedstawienie wykorzystania mechanizmu nawigacji fasetowej w wybranych katalogach online (OPAC) bibliotek narodowych: Biblioteki Kongresu (Library of Congress), Biblioteki Narodowej Rosji (Rossijskaja Nacionalnaja Biblioteka), Biblioteki Brytyjskiej (British Library), Biblioteki Narodowej Walii (The National Library of Wales) i Biblioteki Narodowej Australii (The National Library of Australia). Wybierając do analizy katalogi wymienionych bibliotek kierowano się tym, iż realizują one zbliżone zadania, zaimplementowały już system wyszukiwania fasetowego, ich katalogi funkcjonują na różnych platformach oraz posiadają interfejsy w języku angielskim.

\section{Podstawowe pojęcia}

Na wstępie należy sprecyzować przyjęte w przedstawionych dalej analizach rozumienie pojęć: faseta, klasyfikacja fasetowa, nawigacja fasetowa i wyszukiwanie fasetowe.

Faseta jest terminem zaczerpniętym ze sztuki jubilerskiej - oznacza ukośnie ściętą krawędź kamienia szlachetnego. Zastosowanie tej nazwy przez Ranganathana miało metaforycznie zaakcentować wieloaspektowość zaprojektowanego przez niego systemu klasyfikacji (Bojar, red., 2002, 60). Oszlifowany kamień mieni się różnymi barwami dzięki różnym wielkościom faset i kątom ich nachylenia. Postrzeganie kamienia zmienia się zależnie od perspektywy, przez co każdy, kto nań spogląda może widzieć na swój sposób jego strukturę i barwę. Niewykluczone, iż potrzeba wyjaśnienia filozofii wielokontekstowego sposobu ujęcia organizacji informacji sprawiła, iż to właśnie ten termin stał się charakterystycznym wyróżnikiem klasyfikacji wieloaspektowej. Termin „faseta” w rozumieniu zaproponowanym przez S.R. Ranganathana jest trudny do wyjaśnienia ze względu na zastosowanie do jego wyjaśnienia niestandardowej terminologii, za pomocą której Ranganathan przedstawił swoją teorię klasyfikacji (por. Ungurian, 1975, 13; Bojar, red., 2002, 60). Najogólniejszą definicję fasety podał A.I. Czerny stwierdzając, że jest to:

jedna z kategorii przedmiotów lub ich nazw, stosowanych w danej dziedzinie nauki, techniki lub działalności praktycznej (Czerny, 1981, 257). 
Inna definicja określa fasetę jako drzewo lub gałąź klasyfikacyjną, w której elementy tej samej kategorii zostały zorganizowane według jednego z niezależnych kryteriów podziału (Sosińska-Kalata, 2002, 33). Fasetami są niezależne właściwości lub wymiary, dzięki którym możemy sklasyfikować obiekt (Russell-Rose \& Tate, 2013, 168). Steve Papa - założyciel firmy Endeca - uważa, że fasetowość odpowiada naturze człowieka, ponieważ widzimy świat z wielu perspektyw (Papa, 2006, S6). Stwierdza on, iż nie ma uniwersalnego sposobu kategoryzacji treści - ta sama informacja może okazać się przydatna dla różnych użytkowników z całkowicie różnych powodów. Dlatego fasety stały się popularnym narzędziem zarówno do organizowania informacji, jak i jej wyszukiwania. Sam twórca Klasyfikacji Dwukropkowej przyznawał, iż budowanie faset jest bardziej sztuką niż nauką. Dopiero jednak rozwój technologii informacyjnej ukazał jej prawdziwą potęgę (Weinberger, 2007, 81).

Przewaga fasetyzacji nad wyliczającą strukturą hierarchiczną polega na umożliwieniu opisu własności obiektów według różnych kryteriów, w zależności od kontekstu (Kalbach, 2007, 301). Struktura monohierarchiczna wymaga dopasowywania poszczególnych obiektów do działów lub poddziałów w obrębie jednego drzewa klasyfikacyjnego, fasety zaś tworzą osobne hierarchie odpowiadające różnym aspektom opisu danego przedmiotu (Czerny, 1981, 47). Np. fasetą dla kategorii Samochody osobowe może być rodzaj paliwa; wewnątrz takiej fasety (podkategorii) znajdą się np. takie wartości (pojęcia, przez S. R. Ranganathana zwane izolatami) jak: benzyna, olej napędowy, gaz ziemny itd. (Rys. 1). Inną fasetą w kategorii Samochody osobowe może być typ nadwozia, a zawierać ona będzie wartości odpowiadające temu kryterium opisu samochodów.

Nawigacja fasetowa, zwana także nawigacją kierowana, przegladaniem fasetowym lub - nie całkiem słusznie - wyszukiwaniem fasetowym (Morville \& Callender, 2011, 115; Kalbach, 2007, 301) jest sposobem przeglądania informacji lub zawężania obszernych wyników wyszukiwania w oparciu o wielorakie właściwości (fasety); oferuje użytkownikom wiele dróg dotarcia do każdego dokumentu (Papa, 2006, 6). Wykorzystuje w tym celu pola i wartości metadanych, wskazując użytkownikom opcje, za pomocą których można doprecyzować zapytania (Morville \& Callender, 2011, 115). Jako pierwsza ten rodzaj wyszukiwania wprowadziła na swoich stronach internetowych firma Amazon (Morville \& Callender, 2011, 118). Przeglądanie fasetowe to także alternatywa dla popularnego, tzw. googlowskiego modelu poszukiwania informacji - o czym będzie mowa w dalszej części.

Rysunek 1. Przykład kategorii, faset i ich zawartości dla charakterystyki samochodu osobowego

Samochody osobowe
Rodzaj paliwa
- benzyna
- benzyna + gaz
- olej napędowy
- gaz ziemny
- hybrydowe
- napedd elektryczny
Skrzynia biegów
- manualna
- automatyczna
- półautoamatyczna
Nadwozie
- sedan/limuzyna
- hatchback
- coupe/sportowe
- cabrio
- kombi
- van
- terenowe

Wyszukiwanie fasetowe - określenie, jak wspomniano, często stosowane zamiennie z terminem nawigacja fasetowa (Lemieux, 2009; Morville \& Callender, 2011, 115) - oznacza metodę szukania informacji przez formułowanie zapytań i nawigowanie realizowane za pomocą zintegrowanych systemów wyszukiwania i nawigacji (Hearst, 2009). Termin wyszukiwanie fasetowe można więc uznać za szerszy wobec terminu nawigacja fasetowa rozumianego jako przeglądanie fasetowe. Z punktu widzenia użytkownika wyszukiwanie 
fasetowe obejmuje bowiem stosowanie wyszukiwarki - inicjujące proces poszukiwania, a następnie selekcjonowanie otrzymanych wyników za pomocą wybranych kryteriów wyszukiwania (cech lub filtrów), dzięki którym użytkownik stopniowo eliminuje nieistotne dla niego rezultaty (Tunkelang, 2009, 24). Z perspektywy technologii nawigowanie z użyciem faset jest ściśle zintegrowane z systemem wyszukiwawczym, z czego użytkownik może nie zdawać sobie sprawy. Szerzej to zagadnienie omówiono w części 3.

Tematyka wykorzystywania narzędzi wyszukiwania fasetowego jest w Polsce jeszcze mało popularna. Niewiele jest przykładów rodzimych badań nad zastosowaniem tego mechanizmu w takich systemach informacyjno-wyszukiwawczych, jak katalogi elektroniczne, bazy danych i biblioteki cyfrowe. Do wyjątków należy artykuł Agnieszki Koszowskiej (2009) opublikowany na blogu Biblioteka 2.0. W literaturze anglojęzycznej temat wyszukiwania fasetowego budzi duże zainteresowanie. Wśród autorów zajmujących się nim wymienić można Marti Hearst (2006) - pionierkę badań nad nawigacją fasetową, Kathryn La Barre (2007; 2010), Jamesa Kalbacha (2007), Petera Morville'a i Jeffereya Callendera (2011, 115-122), Steve'a Papa (2006), Stephanie Lemieux (2009), Davida Weinbergera (2007), Tony'ego Russella-Rose'a i Taylera Tyte'a (2013). W języku polskim istnieje natomiast wiele starszych publikacji dotyczących koncepcji i zastosowania klasyfikacji fasetowej w działalności bibliotecznej i dokumentacyjnej. O Klasyfikacji Dwukropkowej pisali m.in. Olgierd Ungurian (1975) oraz Lucyna A. Bielicka i Eugeniusz Ścibor (1982). Ewa Chmielewska-Gorczyca (1993) i Wiesław Babik (1993) zajmowali się zastosowaniem klasyfikacji fasetowej w specjalistycznych systemach informacyjnych. O założeniach teoretycznych klasyfikacji S. R. Ranganathana i innych klasyfikacji fasetowych pisała Barbara Sosińska-Kalata (2002).

\section{Nawigacja fasetowa}

Nawigacja fasetowa (kierowana) jest połączeniem metody klasyfikacji fasetowej i systemu nawigacji. Rozwiązanie to należy do najnowszych osiągnięć w dziedzinie wyszukiwania informacji (Morville \& Callender, 2011, 115). Stosuje się ją w systemach przechowujących i udostępniających bardzo dużą liczbę danych (obiektów) o zwartej strukturze i identyfikowalnych cechach, przechowywanych w jednym miejscu - do których dostęp można uzyskać wieloma drogami.

Przeglądanie fasetowe (Rys. 2) jest również modelem interakcji użytkownika z interfejsem, polegającej na stopniowym zmniejszaniu w zbiorze wyszukiwawczym liczby obiektów odpowiadających potrzebie informacyjnej i dopasowywanie go do coraz bardziej precyzyjnie określonych oczekiwań. Realizowane jest to poprzez wyświetlanie szczegółowych kategorii (faset) jako rezultatu wykonania pewnego działania, np. kliknięcia w określoną fasetę. Można to zilustrować odwołując się do przykładu przedstawionego na rysunku 1. Użytkownik, który chce odnaleźć informacje na temat oferty samochodów osobowych z nadwoziem typu sedan oraz automatyczną skrzynią biegów z głównej kategorii Samochody osobowe, wybiera fasetę nadwozie, a następnie spośród wyświetlonych jej podkategorii (zestawu możliwych bardziej szczegółowych wartości) - podkategorię sedan/limuzyna. Podobnie użytkownik „ustawia filtr” dla rodzaju skrzyni biegów. W ten sposób wyznacza wymagania, które musi spełniać poszukiwany przez niego obiekt. 
Rysunek 2. Zasada działania nawigacji fasetowej

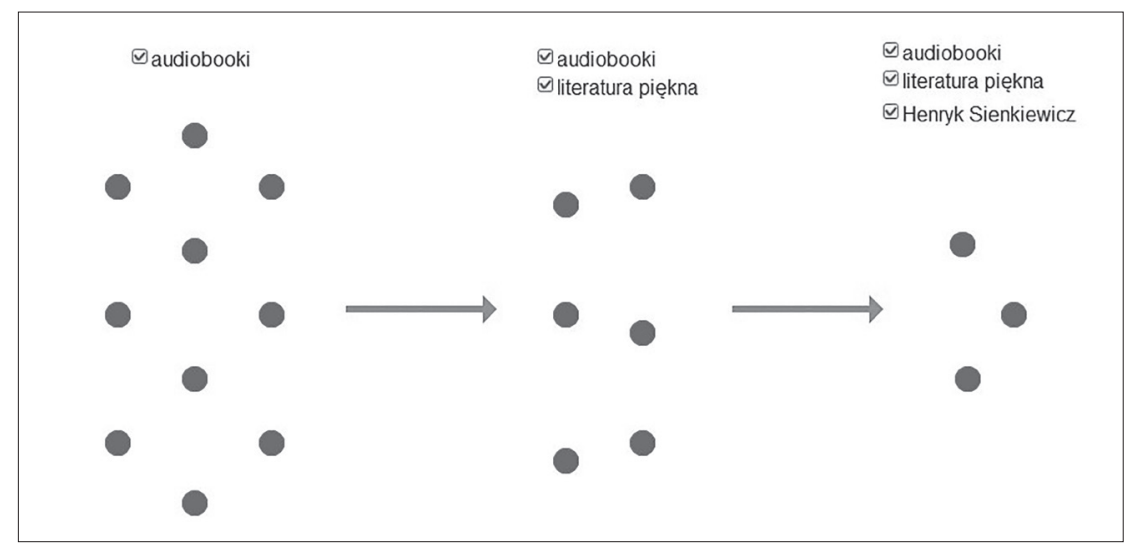

Zgodnie z zasadami nawigacji kierowanej, dostęp do wartości fasety nadwozie, czyli zestawu jej podkategorii, użytkownik otrzymuje po uprzednim wyborze kategorii głównej - w podanym przykładzie jest to kategoria Samochody osobowe. W motoryzacyjnych sklepach internetowych w praktyce często podstawową fasetą warunkującą dalsze poszukiwania jest wybór marki, a następnie modelu samochodu. Innymi fasetami, według których zwykle precyzuje się cechy poszukiwanego pojazdu są: data produkcji, moc silnika, kraj pochodzenia itp. Podobną zasadę stosuje się w systemach nawigacji fasetowej w sklepach internetowych specjalizujących się w produktach z branży komputerowej. Na przykład dla komputera typu PC fasetami mogą być: producent, procesor, pamięć RAM, dysk twardy, system operacyjny (Rys. 3).

Wybór kilku filtrów tworzy opis potrzeby informacyjnej użytkownika. Jest to równocześnie charakterystyka klasy w klasyfikacji fasetowej, której zawartość tej potrzebie odpowiada (Czerny, 1981, 69). Na przykład, klasa dla produktu z kategorii „komputer PC” mogłaby wyglądać następująco: Producent $=$ ASUS, Procesor $=$ Intel Core i5, Częstotliwość $=2000-2500$ $\mathrm{MHz}$, Pamięć RAM = 6 GB, Dysk twardy = 1 TB, Napęd wbudowany = Nagrywarka DVD, System operacyjny $=$ Windows 7 .

Idea faset wykorzystana została także w koncepcji modelu wyszukiwania informacji znanym pod nazwą „strategii budowania bloków” (ang. building blocks strategy). Została ona opisana m.in. przez Stephena P. Hartera (1986, 170-177). Jest to rodzaj tzw. analitycznej strategii wyszukiwania informacji (Marchionini, 2003, 77), w której najpierw identyfikuje się różne fasety (aspekty) charakterystyki potrzeby informacyjnej, a następnie formułuje się zapytanie przyporządkowując każdej fasecie zestaw odpowiednich alternatywnych terminów wyszukiwawczych, połączonych operatorem OR. Dla każdej tak opisanej fasety przeprowadza się wyszukiwanie i uzyskuje zbiór relewantnych trafień (np.opisów dokumentów). Wyniki wyszukiwania dla każdej z faset następnie łączy się operatorami Boole'a (AND, OR, NOT), co prowadzi do uzyskania zbioru dokumentów (pozycji) relewantnych dla całego problemu wyszukiwawczego. Strategia „budowania bloków” pozwala na uproszczenie procesu poszukiwania informacji przez podzielenie go na sekwencje systematycznych i pojedynczych kroków. Stosowana jest przede wszystkim przez ludzi zawodowo zajmujących się wyszukiwaniem informacji (Marchionini, 2003, 78). 
Wyszukiwanie z użyciem nawigacji fasetowej różni się od tradycyjnego, tzw. wyszukiwania parametrycznego (Hunt, 2006, 36; Tunkelang, 2009, 21), w którym użytkownik używa słów kluczowych, starając się przewidzieć jeszcze przed otrzymaniem wyniku, czy dany obiekt istnieje w serwisie (bazie). Wyszukiwanie parametryczne najczęściej przebiega w następujący sposób: szukający wpisuje słowa kluczowe, przegląda kilka pierwszych wyników, a następnie - w przypadku niezadowalających rezultatów wpisuje inne wyrażenia wyszukiwawcze. Taką metodę w piśmiennictwie określa się nazwą "najlepszy pierwszy” (ang. best first; Morville \& Callender, 2010, 106-111). Systemy nawigacji fasetowej zawierają zestawy filtrów, według których użytkownik może „oczyszczać” otrzymaną listę rezultatów. Odnajdywanie informacji ma wówczas charakter stopniowy i przyrostowy - zawężanie obszaru poszukiwań następuje dopiero po otrzymaniu wyników lub wskazaniu kategorii głównej. Kolejne etapy wyszukiwania przebiegają według tego samego schematu - stopniowego doprecyzowania kryteriów, aż do uzyskania końcowego rezultatu. Użytkownicy rozpoczynają więc wyszukiwanie mając niewiele kryteriów wyszukiwania, kończą zaś mając nieduży zbiór wyników dobrze dopasowanych do ich potrzeb (Morville \& Callender, 2010, 87). Ta metoda małych kroków pozwala użytkownikowi łatwiej kontrolować proces wyszukiwania pozostając w zgodzie z podstawowymi zasadami funkcjonalności, nie wymagając od użytkownika wysiłku związanego z „przedzieraniem się” przez liczne przeszkody w postaci skomplikowanego wypełniania pól interfejsów wyszukiwawczych, które tak często widoczne są w katalogach komputerowych (Morville \& Callender, 2010, 87). Wyniki badań wskazują, iż wyszukiwanie fasetowe lepiej wspiera efektywne poszukiwanie informacji niż metoda parametryczna (Hearst, 2006a, 61). Użytkownicy uważają mechanizm fasetowy za bardziej zrozumiały, elastyczny, przy jego użyciu rzadziej wyszukiwanie kończy się niepowodzeniem (Fagan, 2010, 62-63).

W sklepach internetowych i komercyjnych bazach danych wyszukiwanie fasetowe stało się już standardem. Przykładami polskich serwisów internetowych, w których jest ono stosowane są m.in. Ceneo, portal Allegro, EuroAGD, Sorento, Komputronik. Wśród baz danych z wyszukiwarkami fasetowymi wymienić można np.: EBSCO, ProQuest czy SCOPUS. W przypadku produktów konsorcjów oferujących dostęp do baz danych, moduł wyszukiwania
Rysunek 3. Przykład faset w sklepie komputerowym Vobis: podkategorie fasety Komputery stacjonarne (źródło: vobis.pl)

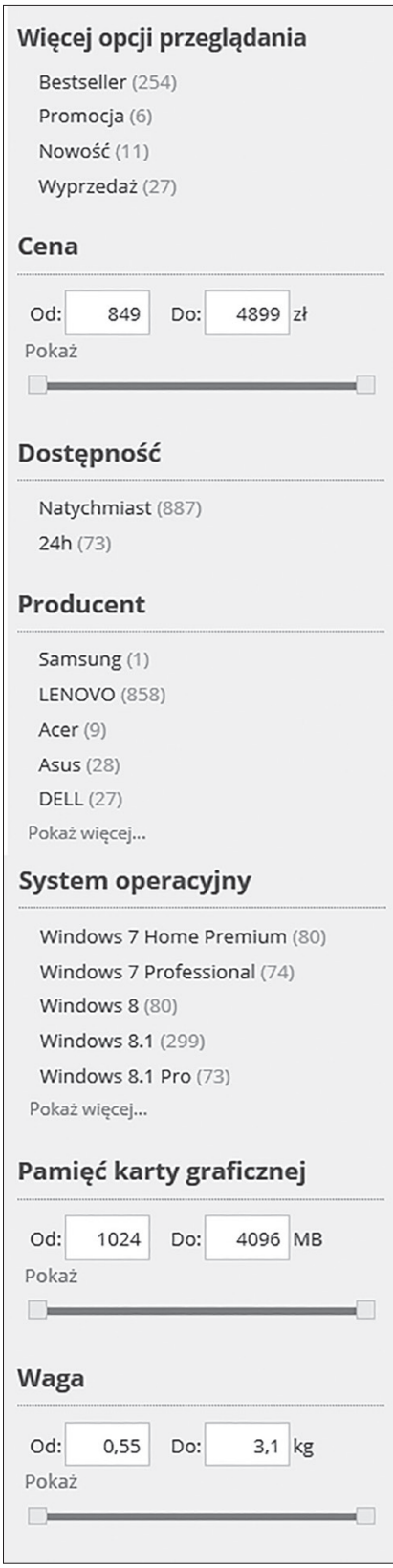


fasetowego jest najczęściej zintegrowany z multiwyszukiwarkami, które równocześnie przeszukują wszystkie zasoby określonego serwisu: katalogi, biblioteki cyfrowe oraz inne udostępniane przez serwis repozytoria cyfrowe.

\section{Architektura informacji systemów wyszukiwania fasetowego}

Omawiając systemy wyszukiwania fasetowego warto przyjrzeć się ich strukturze i choćby ogólnie zaprezentować działanie takiego mechanizmu. W systemie wyszukiwania fasetowego można wyróżnić:

- interfejs - część graficzną systemu, którą użytkownik widzi na ekranie,

- strukturę treści - podział na kategorie i podkategorie,

- mechanizm - oprogramowanie zaimplementowane do zawężania kryteriów i znajdowania informacji,

- modele doświadczeń użytkowników - scenariusze interakcji użytkownika z interfejsem.

Wymienione powyżej elementy planuje się, stosując tzw. wzorce projektowe, czyli poprawne rozwiązania często pojawiających się problemów w projektowaniu systemów informacyjnych. Są one efektem badań i doświadczeń projektantów uzyskanych w ciągu kilkudziesięciu lat, które upłynęły od pojawienia się pierwszych graficznych interfejsów użytkownika.

Rysunek 4. Wertykalny układ nawigacji fasetowej (lewa kolumna) w katalogu

Biblioteki Brytyjskiej (źródlo: http://explore.bl.uk/primo_library/libweb/)

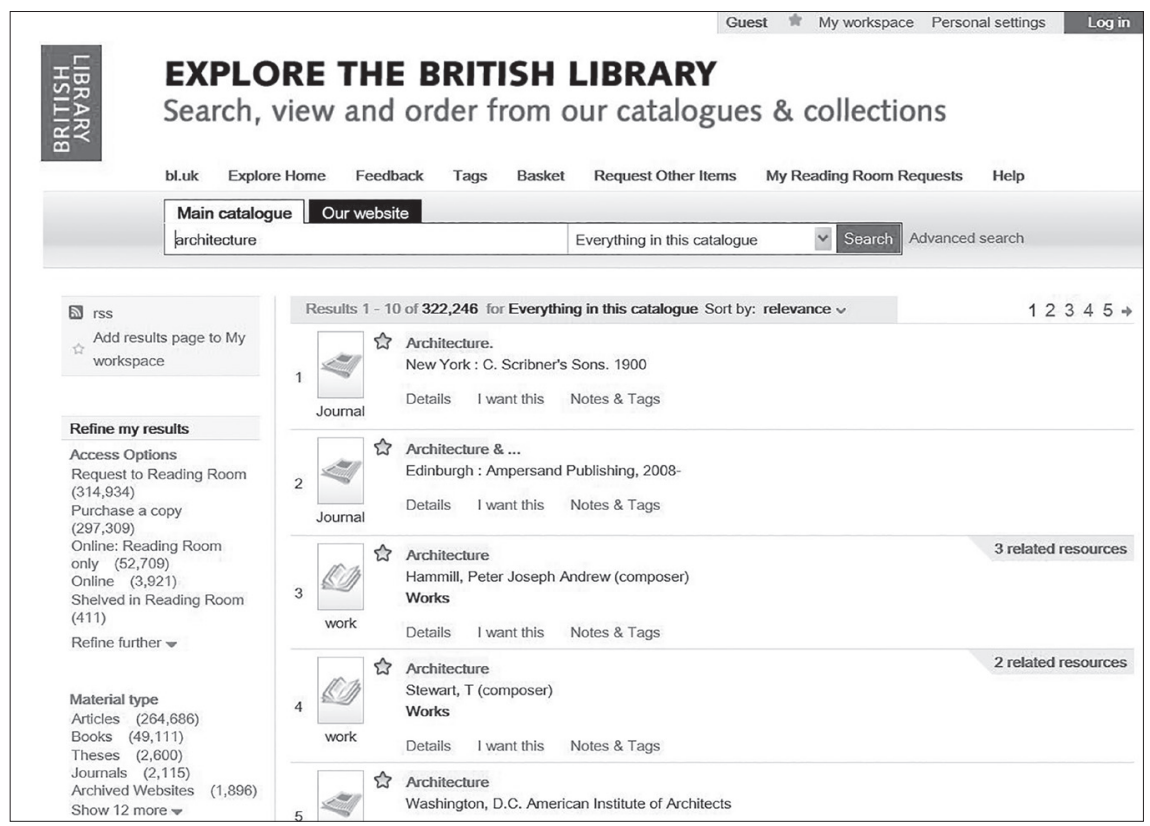

Jednym z takich wzorców projektowych jest wertykalna, horyzontalna lub hybrydowa lokalizacja mechanizmu nawigacji kierowanej w interfejsie graficznym, która uzależniona jest m.in. od liczby faset, układu elementów na ekranie i rozdzielczości ekranu (dostosowanie 
do smartfona, tabletu i monitora), oprogramowania oraz tzw. semantyki fasetowej (Russell-Rose \& Tyler-Tate, 2013, 168).

Wśród katalogów bibliotek, które poddano analizie w dalszej części niniejszego artykułu, w trzech przypadkach filtry fasetowe umieszczono w lewej kolumnie (tj. w: Bibliotece Brytyjskiej, Bibliotece Kongresu i Rosyjskiej Bibliotece Narodowej - Rys. 4). W pozostałych dwóch bibliotekach - w kolumnie prawej (Rys. 5).

Rysunek 5. Nawigacja fasetowa w Bibliotece Narodowej Australii w prawej kolumnie (http://catalogue.nla.gov.au/Search/Home)

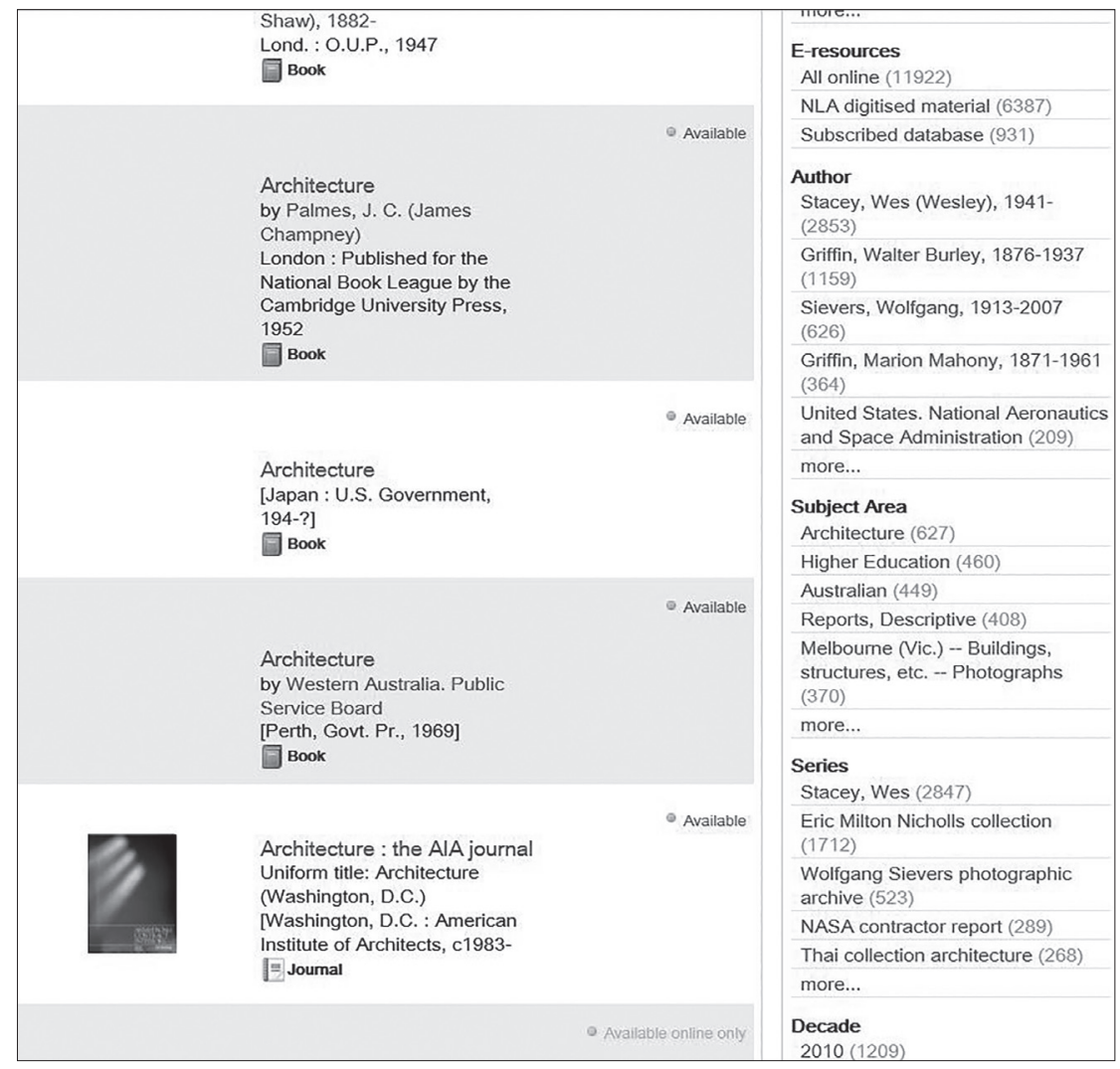

Układ nawigacji fasetowej, podobnie jak organizacja zawartości serwisu, jest jednym z czynników decydujących o przebiegu wyszukiwania. Trudno wskazać jedną metodę lub wzorzec budowania struktury faset, ponieważ na jej kształtowanie wpływa zarówno liczba i rodzaj obiektów stanowiących przedmiot wyszukiwania, jak również zawartość ich charakterystyk wyszukiwawczych, a także typ użytkowników serwisu. We współczesnych systemach informacyjnych elementy charakterystyki wyszukiwawczej są metadanymi odpowiadającymi fasetom, które grupowane są w kategorie. Tak więc układ i zakres metadanych wpływa na liczbę i zawartość faset, które użytkownik widzi na ekranie.

Analizując przykłady nawigacji kierowanej, zarówno w katalogach bibliotek, jak i w sklepach internetowych, trudno określić konkretną liczbę faset, która z jednej strony 
zapewniałaby wyczerpujący opis, a z drugiej nie wywołałaby u szukających poczucia przeładowania informacją. Uważa się np., że 15 faset to zbyt dużo - wraz ze wzrostem liczby faset zwiększa się bowiem też prawdopodobieństwo występowania niejasnych lub wieloznacznych etykiet, które wywołują poczucie chaosu (Lemieux, 2009, 14). Poza tym niełatwo zmieścić kilkanaście faset na jednym ekranie. Jest to ważna wskazówka projektowa, zważywszy, iż użytkownicy niechętnie przewijają strony w celu odczytywania informacji zamieszczonych w ich części, która nie mieści się na ekranie (Lemieux, 2009, 14). Z porównania liczby faset używanych w systemach nawigacji pięciu wybranych bibliotek narodowych wynika, iż najmniejszą liczbę - 6 faset - zastosowano w OPAC-u Biblioteki Narodowej Walii, najwięcej zaś - 11 faset - w katalogu Biblioteki Brytyjskiej (Tab. 1 - zob. część 5 artykułu). Zdarzają się również interfejsy OPAC oferujące aż 19 faset - jak w przypadku katalogu Biblioteki Uniwersytetu Jana Pawła II w Krakowie. Podobne spostrzeżenia o dużym zróżnicowaniu liczby faset stosowanych w OPAC-ach bibliotecznych przyniosła analiza katalogów amerykańskich bibliotek przeprowadzona przez Catherine E. Hall (2011).

Z technologicznego punktu widzenia, działanie wyszukiwania fasetowego zależy od tzw. silnika, czyli oprogramowania, nazywanego też discovery and delivery system (system odkrywania i dostarczania) (Aleph Polska, 2010). Funkcje takiego oprogramowania nie ograniczają się jedynie do przeszukiwania katalogu biblioteki, ale obejmują także inne zasoby, takie jak repozytoria, bazy danych, bibliografie itp. (Ramdeen \& Hemminger, 2012, 702). Ograniczone ramy niniejszego artykułu nie pozwalają jednak na szczegółowe omówienie tych systemów informatycznych.

Poszukiwanie informacji przy użyciu faset opiera się na działaniu wspomnianego mechanizmu wyszukiwawczego, kliknięcie w link fasety uruchamia zapytanie odpowiadające jego wartości (Lemieux, 2009). Odróżnienie wyszukiwania fasetowego od nawigacji fasetowej wynika m.in. z faktu wyodrębnienia w architekturze informacji serwisów internetowych systemów wyszukiwania i nawigacji (Rosenfeld \& Morville, 2003, 66) oraz odpowiadających im dwóch metod szukania informacji - formułowania zapytań i nawigowania (Skórka, 2006, 20-21). Wyszukując fasetowo użytkownik rozpoczyna od wyszukiwarki wpisując w niej zapytanie, a następnie zawęża wyniki stosując system nawigacji fasetowej. Nawigując zaś za pomocą faset użytkownik przegląda jedynie wyniki uzyskane po wybraniu kategorii, nie wpisuje zapytania, lecz kliknięciem wskazuje linki (fasety) towarzyszące wynikom. Tak więc, z punktu widzenia doświadczeń użytkownika (ang. user experience) wyszukiwanie fasetowe polega na stosowaniu dwóch systemów wyszukiwania, z punktu widzenia zaś technologii informacyjnej wykorzystywane jest jedno oprogramowanie (silnik).

Wśród systemów typu discovery and delivery wykorzystywanych w serwisach bibliograficzno-informacyjnych znajdują się m.in.: VuFind firmy Vufind (stosowana w Bibliotece Narodowej Australii), Primo ExLibris (stosowana przez Rosyjską Bibliotekę Narodową i Bibliotekę Brytyjską), Voyager 7.0 również firmy ExLibris (Biblioteka Kongresu) oraz Summons firmy Proqest (Biblioteka Narodowa Walii). Dwie ostatnie platformy zostały zaimplementowane także w kilku polskich bibliotekach akademickich, m.in. w Politechnice Śląskiej w Gliwicach i na Uniwersytecie Mikołaja Kopernika w Toruniu.

Najczęstszym zjawiskiem występującym podczas wyszukiwania z użyciem systemu nawigacji kierowanej jest „oczyszczanie” listy wyników (ang. refining) poprzez wskazywanie cech charakteryzujących szukane zagadnienie. Aby wyszukiwanie mogło być realizowane bez zakłóceń, istotna jest tzw. semantyka fasetowa, czyli odniesienie pojęć użytych 
w nazwach kategorii do przedmiotów, które za ich pomocą zostały opisane (Russell-Rose \& Tate, 2013, 168). W praktyce do zapisu tej relacji wykorzystywane są pola metadanych (Morville \& Callender, 2010, 95), które funkcjonować mogą w postaci dwóch rodzajów interfejsów fasetowych: jedno-selekcyjnych i wielo-selekcyjnych. Jedno-selekcyjne fasety są pogrupowanymi zbiorami linków, obok których (w nawiasach lub bez nich) podana jest liczba obiektów, w których opisie fasety te zostały użyte (zob. Rys. 4). Wybór (kliknięcie) jednej z faset wywołuje natychmiastową zmianę, polegającą na wyświetleniu obiektów spełniających wskazane kryterium; jednocześnie wybrana faseta zostaje wyeliminowana z listy dostępnych filtrów. Taki mechanizm nawigacji fasetowej wykorzystywany jest najczęściej w elektronicznych katalogach bibliotek.

Innym rodzajem interakcji z systemem wyszukiwawczym są interfejsy wielo-selekcyjne. Na pierwszy rzut oka od interfejsów jedno-selekcyjnych różnią się one formą prezentacji graficznej - z reguły zaprojektowane są w postaci tzw. pól wyboru (ang. checkbox) (Rys. 6). Dają możliwość zaznaczenia kilku filtrów jednocześnie, a następnie wyświetlają wynik po kliknięciu przycisku „Szukaj” lub „Filtruj”. Mechanizm ten jednak może zwrócić wynik zerowy, jeżeli użytkownik wybierze filtry, które wzajemnie się wyeliminują. Np. stałoby się tak, gdyby w przykładzie z rysunku 2 zaznaczono wartości: audiobooki, literatura piękna, Henryk Sienkiewicz oraz data wydania: 1980 (kiedy nie istniały jeszcze audiobooki). Mechanizm ten bowiem może łączyć zaznaczone kryteria - podobnie jak w interfejsach wyszukiwania zaawansowanego w polach indeksowych - koniunkcyjnie, a więc operatorem AND. Rozwiązaniem tego problemu jest zastosowanie trybu wielo-selekcyjnego rozłącznego, w którym kryteria wyszukiwania łączy się operatorem alternatywy - OR (Russell-Rose \& Tate, 2013, 169).

Rysunek 6. Fasety w postaci pól wyborów (checkboxów). Fragment ekranu katalogu Worldcat.org

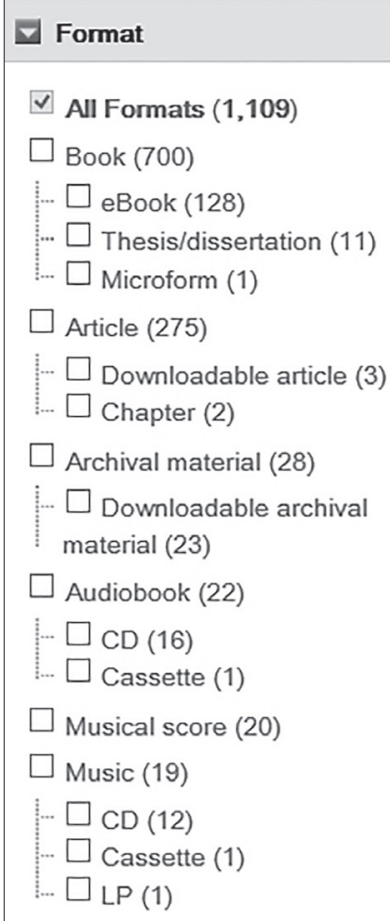

Show more...

Struktura faset w nawigacji kierowanej realizuje model tzw. postępującego ujawniania tajemnic, czyli wskazywania szczegółowych wartości faset dopiero na drugim lub trzecim poziomie hierarchicznej organizacji faset w systemie nawigacji. Ten wzorzec projektowy jest powszechny w wyszukiwaniu fasetowym zarówno w serwisach komercyjnych, jak i systemach informacyjnych. Podczas nawigowania z użyciem faset użytkownicy obserwują wyniki uzyskiwane w rezultacie wyboru poszczególnych kategorii, mogąc nimi manipulować, tj. wyłączać i włączać filtry, po to, by np.zmieniać liczbę wyświetlanych wyników (Rys. 7a-d). W opisywanych interfejsach stosowane są różne metody wspierania interakcji przez prezentację aktualnego stanu wyszukiwania za pomocą faset: tzw. ścieżka okruszków (Biblioteka Narodowa Walii), kontrolki (Rosyjska Biblioteka Narodowa, Biblioteka Kongresu i Biblioteka Brytyjska) oraz wyróżnienie linków (Biblioteka Narodowa Australii) (Rys. 6). 
Standardowy wygląd filtrów do zawężania zapytań, czyli tzw. stan domyślny nawigacji fasetowej, wyświetlany jest z reguły na dwa sposoby, tj. domyślnie zamknięty lub domyślnie otwarty. Interfejsy wszystkich katalogów bibliotecznych poddanych analizie w następnej części artykułu operują fasetami domyślnie otwartymi, co z jednej strony powoduje rozciągnięcie treści na kolejne ekrany, z drugiej jednak ułatwia uchwycenie tzw. tropu informacji (Russell-Rose \& Tate, 2013, 173-174), zachęcając do dalszych poszukiwań i kontrolowania przebiegu interakcji.

Rysunek 7. Wizualizacja faset zaznaczonych podczas wyszukiwania informacji. (a) Biblioteka Brytyjska, (b) Biblioteka Kongresu, (c) Biblioteka Narodowa Walii, (d) Biblioteka Narodowa Australii

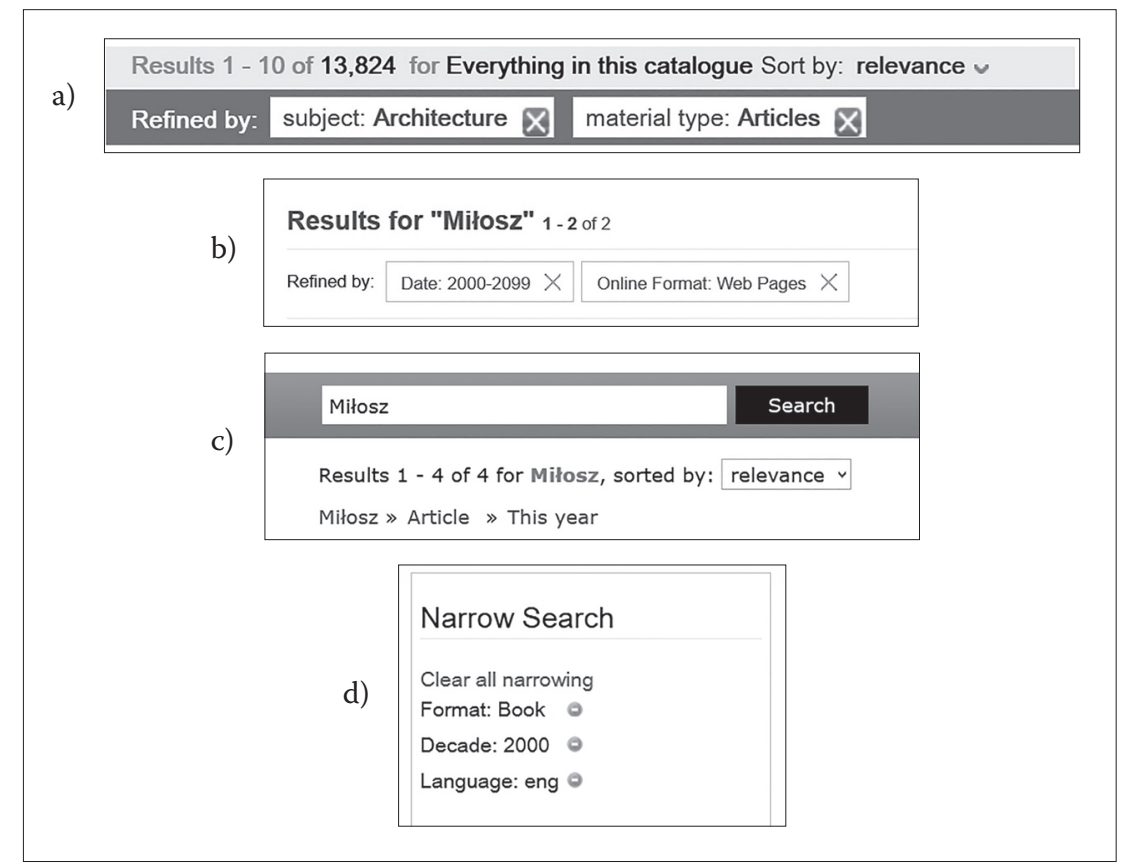

Dobrze zaprojektowana architektura systemu nawigacji fasetowej jest efektem rozpoznania potencjalnych zachowań (doświadczeń) użytkowników korzystających z określonych narzędzi w systemie wyszukiwawczym. Doświadczenia takie bada się za pomocą testów użyteczności, obserwacji i wywiadów, a następnie opracowuje w postaci tzw. scenariuszy użycia (Spencer, 2010, 91-92). Zawierają one charakterystykę użytkownika końcowego, opis przykładowego problemu wyszukiwawczego, a także najważniejsze etapy występujące podczas poszukiwania, uzupełnione o szkice interfejsów, z których użytkownik będzie korzystał. W przypadku wyszukiwania fasetowego scenariusz przedstawiać może sposoby (ścieżki), jakimi przypuszczalnie posłuży się potencjalny użytkownik do realizacji zadania. W opracowaniu takich scenariuszy przydatna jest znajomość modeli strategii wyszukiwania informacji. Jednym z nich jest tzw. technika „zbierania jagód” (ang. berrypicking technique), opisana przez Marcię J. Bates (1986). Użytkownik wykorzystując informacje (,jagody”) zdobyte podczas szukania, wchodzi w interakcję z systemem - po uzyskaniu danej informacji aktualizuje swój stan wiedzy, co doprowadza go do kolejnej informacji itd., aż do zaspokojenia potrzeby informacyjnej. Kolejnym przykładem może być strategia „rosnącej perły” 
(ang. citation pearl growing) (Harter, 1986, 183-184). „Perła” to metafora relewantnego dokumentu (dokumentów), który jest podstawą do wyselekcjonowania faset (np. metadanych takich jak słowa kluczowe i odniesienia bibliograficzne) używanych w poszukiwaniu innych dokumentów relewantnych do danej tematyki (Harter, 1986, 183-184; Morville \& Callender, 2010, 72). Innym modelem zachowania użytkowników jest tzw. teoria szukania informacji (ang. information foraging theory), w której dla scharakteryzowania aktywności użytkownika zastosowano analogię do zachowania zwierząt szukających pożywienia. Poszukiwaniu informacji towarzyszy podobny mechanizm kognitywny, jak w przypadku poszukiwania pożywienia (Hearst, 2009, 73). Szukanie pożywienia odbywa się za pomocą zapachu, śladów itp., poszukiwanie zaś informacji za pomocą wspomnianego już tropu informacji - takim tropem mogą być właśnie fasety i ich wartości.

Podsumowując zagadnienia architektury informacji systemu wyszukiwania fasetowego warto wskazać najważniejsze priorytety w jego projektowaniu:

a. wybór podstawowego trybu selekcji: pojedynczej (za pomocą linków) lub wielokrotnej (pola wyboru),

b. umożliwienie oczywistego i spójnego sposobu cofnięcia wyboru filtrów,

c. wszystkie filtry powinny być łatwo dostępne,

d. interfejs powinien zawierać wartości jedynie tych filtrów, które odpowiadają dostępnym obiektom lub asortymentowi,

e. jeden z filtrów powinien być dopasowany do wszystkich obiektów (Nudelman, 2009).

\section{Zastosowanie nawigacji fasetowej w katalogach bibliotecznych}

Mechanizm wyszukiwania fasetowego wprowadziła jako pierwsza biblioteka North Carolina State University w 2006 r. Do obsługi OPAC-a zaimplementowano platformę ProFind firmy Endeca (La Barre, 2007, 78). Implementacje poprzedziły dyskusje w środowisku, których pokłosiem stał się m.in. raport pt. Rethinking how we provide bibliographic services for the University of California. (La Barre, 2007, 78-79). Jednym z motorów zmian w projektowaniu katalogów elektronicznych były badania użytkowników oraz ich potrzeb informacyjnych opublikowane m.in. w raportach Sue Sparks (2005) i Research Information Network (RIN, 2006). Wprowadzenie nowych funkcjonalności w OPAC-ach uznano za swoistą rewolucję. Katalogi wyposażone w te nowe narzędzia nazwano katalogami trzeciej generacji, które stopniowo zastępują trudniejsze w obsłudze katalogi tzw. drugiej generacji, z lat 80. i 90. (La Barre, 2007, 80). Głównymi powodami trudności w korzystaniu z katalogów drugiej generacji było ich niedopasowanie do potrzeb użytkowników. W okresie, gdy powstawały dostosowywano je raczej do potrzeb bibliotekarzy, nie poświęcając dużej uwagi użyteczności i funkcjonalności interfejsów tych narzędzi, a od użytkowników wymagano, aby uczyli się ich obsługi (Sadeh, 2013).

Pionierami we wprowadzaniu katalogów nowej generacji są przede wszystkim biblioteki uniwersyteckie na zachodzie Europy oraz w Stanach Zjednoczonych, a także pięć bibliotek narodowych, których katalogi na potrzeby niniejszego artykułu poddane zostały analizie w okresie od czerwca do września 2014 r. Należy zaznaczyć, iż nie są to obecnie jedyne przykłady implementacji fasetowego sposobu wyszukiwania przez biblioteki narodowe. Oprócz nich nawigację fasetową w swoich OPAC-ach wprowadziły już m.in. biblioteki narodowe Francji, Finlandii i Norwegii. 
Tabela 1. Zestawienie nazw faset w wybranych OPAC-ach bibliotek narodowych

\begin{tabular}{|c|c|c|c|c|}
\hline $\begin{array}{c}\text { Biblioteka } \\
\text { Kongresu (Stany } \\
\text { Zjednoczone) }\end{array}$ & $\begin{array}{c}\text { Biblioteka } \\
\text { Narodowa Rosji }\end{array}$ & $\begin{array}{l}\text { Biblioteka } \\
\text { Brytyjska }\end{array}$ & $\begin{array}{c}\text { Narodowa } \\
\text { Biblioteka } \\
\text { Walii }\end{array}$ & $\begin{array}{c}\text { Biblioteka } \\
\text { Narodowa } \\
\text { Australii }\end{array}$ \\
\hline $\begin{array}{l}\text { Original Formats } \\
\text { Online Formats } \\
\text { Dates } \\
\text { Sites and Collec- } \\
\text { tions } \\
\text { Contributors } \\
\text { Subjects } \\
\text { Locations } \\
\text { Languages }\end{array}$ & $\begin{array}{l}\text { Resource Type } \\
\text { Creation Date } \\
\text { Language } \\
\text { Creator } \\
\text { Collection } \\
\text { Series Title } \\
\text { Publisher } \\
\text { BBK } \\
\text { Topic } \\
\text { Code of Speciality }\end{array}$ & $\begin{array}{l}\text { Access Options } \\
\text { Material Type } \\
\text { Author/Contributor } \\
\text { Subject } \\
\text { Collection } \\
\text { Creation date } \\
\text { Language } \\
\text { Publisher } \\
\text { Genre } \\
\text { Journal Title } \\
\text { Additional Feature }\end{array}$ & $\begin{array}{l}\text { Library format } \\
\text { Author } \\
\text { Subject } \\
\text { Language } \\
\text { Series } \\
\text { Range }\end{array}$ & $\begin{array}{l}\text { Format } \\
\text { E-resources } \\
\text { Author } \\
\text { Subject Area } \\
\text { Series } \\
\text { Decade } \\
\text { Language } \\
\text { Publisher } \\
\text { Geographic } \\
\text { Occupation }\end{array}$ \\
\hline
\end{tabular}

W tabeli 1 zestawiono listy faset znajdujących się w interfejsach wyszukiwawczych wybranych bibliotek narodowych. Starano się uzyskać ich pełny wykaz, w tym celu zadawano dwa różne zapytania wyszukiwawcze: Miłosz i architecture. Zabieg taki umożliwił sprawdzenie faktycznej liczby faset, w zależności od kategorii głównej poszukiwanego tematu.

Na podstawie zestawienia w tabeli 1 zauważyć można niejednolitość w etykietach oznaczających: autorstwo $(A u-$ thor, Creator), temat publikacji (Topic, Subject), datę wydania (Date of Publication, Creation Date, Range, Publication Year, Decade), formę dokumentu (Original formats, Online formats, Resource type, Library format, Format).

Różnorodność nazewnictwa faset (kategorii) dla użytkownika korzystającego z wielu katalogów może być uciążliwa i wprowadzać w błąd. Przyczyn tej różnorodności można upatrywać w rodzaju księgozbioru, specyfice biblioteki, może być ona też związana ze stosowaniem odmiennych platform odpowiedzialnych za funkcjonowanie systemu wyszukiwawczego. Ciekawe, że różnice w etykietach występują nawet między bibliotekami $\mathrm{z}$ angielskiego obszaru językowego. W tabeli 1 przedstawiono jedynie główne fasety, których liczba zmienia się w zależności od zaznaczonych kryteriów opisu wyświetlanych obiektów. Nie umieszczono natomiast podkategorii (wartości), ponieważ ich liczba i typy zależą od księgozbioru. Na przykład w katalogu Biblioteki Kongresu wyodrębniono dwie główne kategorie: Available online oraz All items. Warunkują one dalsze przeszukiwanie, wyświetlając te filtry, które odnoszą się (lub nie) do dokumentów dostępnych tylko w Internecie. Biblioteka Narodowa Walii
Rysunek 8. OPAC Biblioteki Brytyjskiej. Fragment mapy nawigacji fasetowej

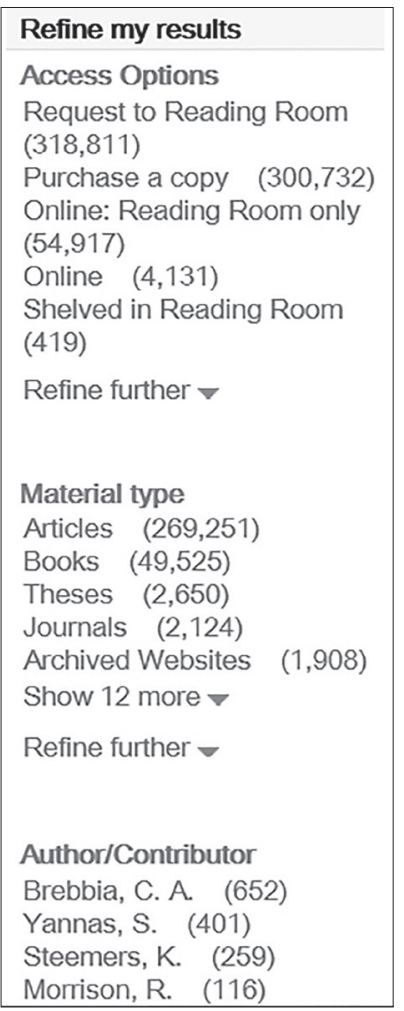


zastosowała podobny wzorzec, tworząc więcej kategorii głównych: All locations, Printed works, Archives and Manusripts, Online, Electronic legal deposit.

Standardowy interfejs nawigacji fasetowej składa się z dwóch poziomów: pierwszy zawiera listę opcji głównych, drugi - wartości wewnątrz każdej z nich z liczbą rezultatów spełniających daną cechę (Rys. 8). Najczęstszą praktyką jest prezentowanie wewnątrz każdej fasety najwyżej pięciu filtrów uporządkowanych według ważności (Lemieux, 2009, 15), oczywiście może ich być mniej w zależności od uzyskanych rezultatów. Tak jest np. w OPAC-u Biblioteki Narodowej Australii; $\mathrm{w}$ razie potrzeby zapoznania się z pozostałą, niewidoczną listą filtrów użytkownik może skorzystać z linku more. Podobnie jest w katalogu Biblioteki Brytyjskiej, tu jednak link rozwijający pozostałe fasety brzmi: Refine further, Show 12 more (Rys. 8). W katalogu Biblioteki Kongresu domyślnie wyświetlanych jest aż dziesięć wartości na drugim poziomie. Niejednakową liczbę wartości stwierdzono w interfejsie katalogu Rosyjskiej Biblioteki Narodowej, gdzie w wersji anglojęzycznej, w fasecie Creator pokazano 7 filtrów, a pod Creation date - tylko 3. W obu przypadkach istnieje możliwość rozwinięcia listy wariantów do wyboru, dostępnych po kliknięciu More options.

W interfejsach serwisów internetowych z wyszukiwaniem fasetowym coraz częściej posługiwać się można widgetami, dzięki którym manipulacja fasetami staje się łatwiejsza i ciekawsza. W OPAC-ach nie są one jeszcze bardzo popularne. Można skorzystać z takiego mechanizmu w postaci tzw. suwaka podwójnego w katalogu BN Rosji. Niezwykle atrakcyjny wizualnie i jednocześnie użyteczny jest widget prezentowany w postaci tzw. chmury wyrażeń (ang. word cloud) (Rys. 9). Taki produkt o nazwie AquaBrowser ${ }^{1}$ udostępniany jest m.in. w interfejsie OPAC-a Biblioteki Narodowej Walii. Ułatwia on wybór terminów powiązanych z poszukiwanym słowem kluczowym.
Rysunek 9. Wyświetlanie podobnych terminów po wpisaniu słowa „Miłosz”

w postaci tzw. chmury wyrażeń generowanej przez oprogramowanie

AquaBrowser Serialssolutions. Biblioteka Narodowa Walii.

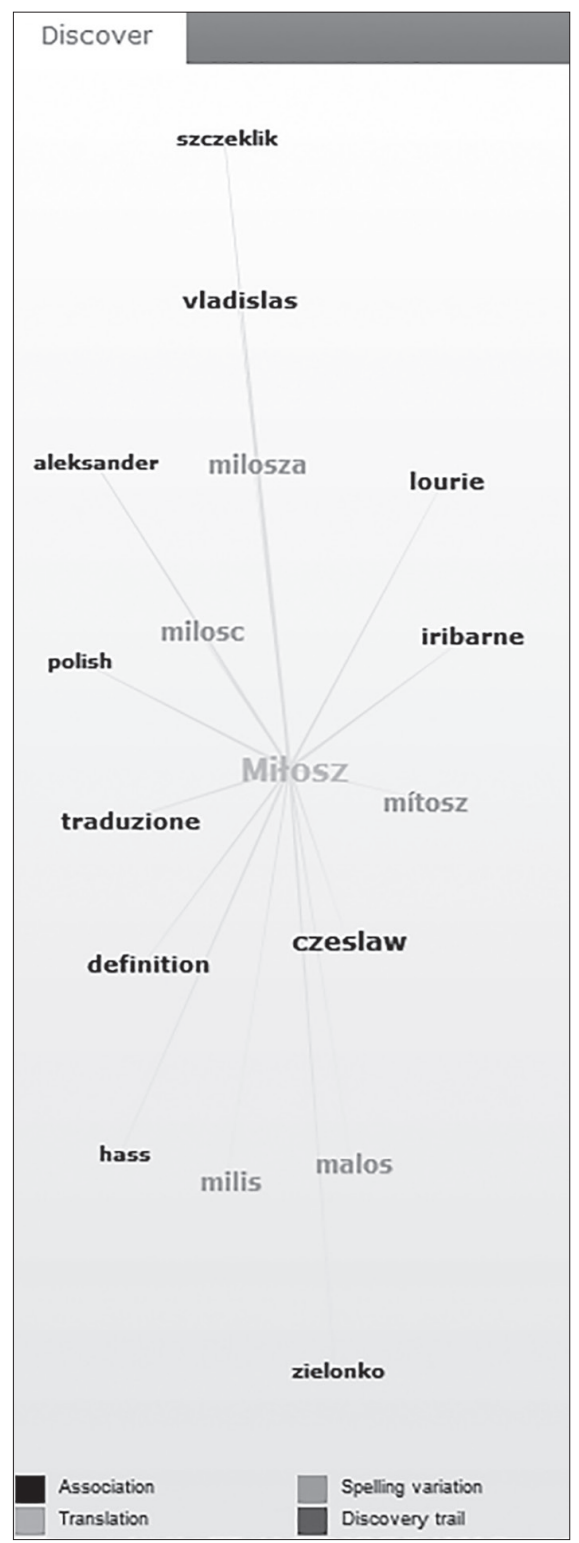

${ }^{1}$ AquaBrowser. Discovery Layer: www.serilalssolutions.com 


\section{Przyszłość fasetyzacji}

Na podstawie literatury przedmiotu oraz obserwacji współczesnych trendów w projektowaniu środowisk informacyjnych można wysunąć tezę, iż nie ma już odwrotu od wyszukiwania fasetowego, ponieważ użytkownicy polubili ten sposób szukania informacji (Fagan, 2010, 62). W najbliższych latach niewątpliwie zwiększy się liczba katalogów oferująca tę funkcjonalność. Dziś już wiadomo, że firma VTLS (obecnie Innovative), producent systemu Virtua, wprowadziła nową wersję swojego zintegrowanego systemu bibliotecznego o nazwie CHAMO Discovery, który m.in. posiada moduł wyszukiwania fasetowego. Podczas pracy nad niniejszym tekstem w Polsce wdrożyły go m.in. biblioteki: Uniwersytetu Jagiellońskiego, Uniwersytetu Jana Pawła II w Krakowie, Uniwersytetu Pedagogicznego w Krakowie i Akademii Górniczo-Hutniczej. Moduł taki posiada również KOHA - inny stosowany w Polsce zintegrowany system biblioteczny.

Wprawdzie mechanizm wyszukiwania za pomocą faset wprowadziło w swoich katalogach już wiele bibliotek, zarówno uniwersyteckich, jak i publicznych, jednak nie na tyle dużo szczególnie w naszym kraju - aby można było uznać to za powszechne zjawisko. Zmiana oprogramowania to dla większości bibliotek ogromny wydatek. W czasie opracowywania niniejszego artykułu stwierdzono, że wiele bibliotek narodowych nie zaimplementowało jeszcze nawigacji fasetowej. Należą do nich m.in. Biblioteka Narodowa w Warszawie oraz Szwajcarska Biblioteka Narodowa. Nie miał jej wówczas również polski katalog centralny NUKAT, w ograniczonym zakresie stosował zaś katalog rozproszony bibliotek polskich - KaRo.

Pomimo nowych funkcji i atrakcyjniejszej szaty graficznej nowoczesnych katalogów bibliotecznych, ich głównymi zadaniami są nadal znajdowanie, identyfikacja, selekcjonowanie i otrzymywanie (La Barre, 2007, 79). Wyraźnie zwiększa się jednak łatwość posługiwania się tymi katalogami, w coraz szerszym zakresie pozwalają one też integrować procesy przeszukiwania różnych zasobów informacyjnych.

W niniejszym artykule nie omówiono wyszukiwania fasetowego w innych systemach typu discovery and delivery, jak np. bazy danych czy biblioteki cyfrowe. Jest to materiał do dalszych badań. Dzięki uzyskanym wynikom być może udałoby się wyłonić dobre praktyki tworzenia i projektowania takich systemów w polskich realiach. Umiejętność fasetowej organizacji treści (dokumentów, produktów itp.) jest obecnie bardzo przydatna i poszukiwana w branży użyteczności i architektury informacji. Warto więc również uwzględnić tematykę faset $\mathrm{w}$ kształceniu akademickim w kontekście projektowania organizacji informacji. Każdy, kto zetknął się z klasyfikacją w praktyce może zgodzić się ze stwierdzeniem, iż wyszukiwanie fasetowe jest jak gra w szachy - łatwo zrozumieć reguły, ale potrzeba lat, aby osiągnąć biegłość (Tunkelang, 2009, 25).

\section{Bibliografia}

Aleph Polska (2010). Exlibris Primo. Discovery and Delivery [online]. Aleph Polska [31.10.2014], http://www.aleph.pl/produkty/primo/

Babik, W. (1993). Nowe rozwiązania klasyfikacyjne dla systemów informacyjno-wyszukiwawczych materiałów kartograficznych. Zagadnienia Informacji Naukowej 2(62), 63-85.

Bates, M. J. (1989). The Design of Browsing and Berrypicking Techniques for the Online Search Interface [online]. [3.09.2014], http://pages.gseis.ucla.edu/faculty/bates/berrypicking.html 
Bielicka, L. A.; Ścibor, E. (1982). Języki informacyjne. Rodzaje i zastosowanie w działalności informacyjnej. Warszawa CINTE.

Bojar, B., red. (2002). Stownik encyklopedyczny informacji, języków i systemów informacyjno-wyszukiwawczych. Warszawa: Wydaw. SBP.

Chmielewska-Gorczyca, E. (1993). Tezaurus nazw geograficznych Biblioteki Sejmowej. Zagadnienia Informacji Naukowej 2(62), 123-140.

Czerny, A. I. (1981). Teoria wyszukiwania informacji. Warszawa: PWN.

Fagan, J. C. (2010). Usability Studies of Faceted Browsing: A Literature Review. Information Technology and Libraries, June, 58-66.

Flamenco Search (b.d.). The Flamenco Search Interface Project [online]. UC Berkeley School of Information [4.04.2013], http://flamenco.berkeley.edu/index.html

Hall, C. E. (2011). Faceted-based library catalogs: A survey of the landscape [online]. Proceedings of the American Society for Information Science and Technology, 48(1), 1-8, [3.09.2014], http://www. asis.org/asist2011/proceedings/submissions/195_FINAL_SUBMISSION.pdf

Harris, D. (2011). Why Oracle bought big data veteran Endeca [online]. Gigaom [5.04.2013], http://gigaom.com/2011/10/18/why-oracle-bought-big-data-veteran-endeca/

Harter, S. P. (1986). Online Information Retrieval: Concepts, Principles, and Techniques. Orlando: Academic Press.

Hearst, M. A. (2006a). Clustering versus Faceted Categories for Information Exploration. Communications of the ACM, April 49(4), 59-61.

Hearst, M. A. (2006b). Design Recommendations for Hierarchical Faceted Search Interfaces [online]. The ACM SIGIR Workshop on Faceted Search. August [4.04.2013], http://flamenco.berkeley.edu/ papers/faceted-workshop06.pdf

Hearst, M. A. (2009). Search User Interfaces. New York: Cambridge University Press.

Hunt, K. (2006). Faceted Browsing. Breaking the Tyranny of Keyword Searching[online]. Felicitier 52(1), 36-37 [2.09.2014], http://www.cla.ca/AM/Template.cfm?Section=Vol_52_No_1

Kalbach, J. (2007). Designing Web Navigation. Beijing: O’Reilly.

Koszowska, A. (2009). Społeczny OPAC - nowe trendy. Część 1. [online]. Biblioteka 2.0. Blog społeczności czytelników i bibliotekarzy cyfrowych [10.09.2014], http://blog.biblioteka20.pl/?p=107

La Barre, K. (2007). Faceted Navigation and Browsing Features in New OPACs: Robust Support for Scholarly Information Seeking? Knowledge Organization 34(2), 78-90.

La Barre, K. (2010). Facet analysis. Annual Review of Information Science and Technology, 44(1), 243-284.

Lemieux, S. (2009). Designing for faceted search. Knowledge Management World, 18(3), March, 14-15.

Marchionini, G. (2003). Information Seeking in Electronic Environments. Cambridge: University Press.

Morville, P.; Callender, J. (2011). Wzorce wyszukiwania. Projektowanie nowoczesnych wyszukiwarek. Gliwice: Helion.

Nudelman, G. (2009). Best Practices for Designing Faceted Search Filters [online]. The UXmatters [27.08.2014], http://www.uxmatters.com/mt/archives/2009/09/best-practices-for-designingfaceted-search-filters.php\#sthash.VWDwteRz.dpuf

Papa, S. (2006). The Faceted Navigation and Search Revolution. Knowledge Management World, 15(4), April, 6-7.

Pirolli, P.; Card, S. K. (1999). Information foraging. Psychological Review, 106(4), 643-675.

Ramdeen, S.; Hemminger, B. M. (2012). A Tale of Two Interfaces: How Facets Affect the Library Catalog Search Experience. Journal of the American Society and Information Science and Technology, 63(4), 702-715.

RIN (2006). Researchers and discovery services Behaviour, perceptions and needs [online]. Research Information Network [17.07.2014], http://www.rin.ac.uk/system/files/attachments/Researchers-discovery-services-report.pdf 
Rosenfeld, L.; Morville, P. (2003). Architektura informacji w serwisach internetowych. Gliwice: Helion.

Russell-Rose, T.; Tate, T. (2013). Designing the search experience. The Information Architecture of Discovery. Amsterdam: Morgan Kaufman.

Sadeh, T. (2013). From Search to Discovery [online]. IFLA Library [10.09.2014], http://library.ifla. org/104/1/098-sadeh-en.pdf/

Skórka, S. (2006). Użytkownicy systemów hipertekstowych. Strategie poszukiwania informacji w edukacyjnym serwisie internetowym. Kraków: Wydaw. Naukowe Akademii Pedagogicznej.

Sosińska-Kalata, B. (2002). Klasyfikacja. Struktury organizacji wiedzy, piśmiennictwa i zasobów. Warszawa: Wydaw. SBP.

Spencer, D. (2010). A Practical Guide to Information Architecture. Penarth: Five Simple Steps.

Sparks, S. (2005). JISC disciplinary differences report [online]. London: Rightcom [17.07.2014], http:// www.jisc.ac.uk/uploaded_documents/Disciplinary\%20Differences\%20and\%20Needs.doc

Tunkelang, D. (2009). Faceted Search. San Rafael: Morgan \& Claypool Publishers.

Ungurian, O. (1975). Teoria i praktyka klasyfikacji fasetowej S. R. Ranganathana. Warszawa: CINTE.

Weinberger, D. (2007). Everything is miscellaneous: the power of the new digital disorder. New York: Times Books.

\title{
Facets Rediscovered. Integration of Navigation and Information Organization Systems
}

\begin{abstract}
Purpose/thesis: The paper is intended to present the idea of faceted navigation and information retrieval and their application in the library catalogs.

Approach/methods: The author discusses access to information resources with facets corresponding to search criteria, basic features of architecture of faceted retrieval systems and models of users' information behavior used to build such systems. The comparative analysis covers faceted information retrieval in five online public accessed catalogs of national libraries: British Library, Library of Congress, National Library of Wales, National Library of Australia and National Library of Russia. Data for the analysis were collected from June to September 2014.

Results and conclusions: The evolution of information technologies has led to the rebirth of S. R. Ranganathan's multifaceted system of contents classification, facilitating the retrieval of information via several different ways. Faceted classification is one of most often used methods of content organization in commercial websites, although most authors of systems based on this classification are not aware of this fact. Facets used to refine search results are common in commercial websites but this innovation remains fairly unknown to library catalogs and no best practices and examples to follow have been identified so far. The author finds differences in number of categories available and terminology used in faceted retrieval interfaces in the library catalogs selected for the research. Originality/value: The issues of facets and faceted classification in search and retrieval systems are rarely discussed in Poland. The author does not know any research on the application of such mechanism in library and information online services.
\end{abstract}

Keywords

Information architecture. Facets. Library catalogs. Faceted classification. Faceted navigation. Discovery \& Delivery systems. Faceted information retrieval. 
Dr STANISŁAW SKÓRKA jest dyrektorem Biblioteki Gtównej Uniwersytetu Pedagogicznego w Krakowie $i$ adiunktem $w$ Instytutcie Informacji Naukowej $i$ Bibliotekoznawstwa UP. Prowadzi badania dotyczace architektury informacji i użyteczności elektronicznych katalogów, bibliotek cyfrowych oraz innych systemów typu discovery and delivery. Jest wspóttwórca kierunku studiów licencjackich pn. Architektura informacji realizowanego w macierzystej uczelni. Wybrane publikacje: Systemy nawigacji w przestrzeni mówionej: analiza porównawcza. W: B. Sosińska-Kalata, E. Chuchro, red. Nauka o informacji w okresie zmian: praca zbiorowa. Warszawa 2013, 401-413; Ewaluacja jakości bibliotek cyfrowych w ujęciu architektury informacji. W: XVIII edycja seminarium w cyklu Digitalizacja: Biblioteki cyfrowe - systemy zarzadzania, obstugi oraz kryteria oceny. Warszawa 2012, 155-186; Architekt informacji: kreator przestrzeni informacyjnych. Przeglad Biblioteczny 2011, 79(1), 47-61.

Kontakt $z$ autorem:

skorka@up.krakow.pl

Uniwersytet Pedagogiczny w Krakowie

Biblioteka Główna, ul. Podchorążych 2

30-084 Kraków 